\title{
Pengaruh Pelayanan Remaja Terhadap Pertumbuhan Rohani Remaja Usia 12-15 Tahun Di Gereja Kemah Injil Indonesia Jemaat Antutan Kalimantan Utara
}

\author{
Ester Ester, Meily Lunanta
}

Sekolah Tinggi Filsafat Theologia Jaffray Makassar

\begin{abstract}
Abstrak
Pelayanan merupakan suatu usaha pemberian bantuan atau pertolongan kepada orang lain baik berupa materi maupun non materi agar orang yang menerima pelayanan tersebut dapat mengatasi masalahnya sendiri. Dalam hal ini pelayanan dilakukan oleh pembina remaja untuk membimbing remaja bertumbuh dalam rohani. Tujuan dari penelitian yang dilakukan adalah untuk mengetahui sejauh mana pengaruh pelayanan remaja terhadap pertumbuhan rohani remaja usia 12-15 tahun di Gereja Kemah Injil Indonesia Kalimantan Utara. Pelayanan remaja yang diberikan kepada remaja perlu mempersiapkan pelayanan yang kreatif dan pelayanan yang diberikan harus mengikuti keteladanan Yesus dalam malakukan pelayanan dan pengajaran dengan tujuan akhir yaitu pertobatan, pembaharuan hidup serta kekuatan akan firman Allah dan dapat mempraktekkannya dalam kehidupan sehari-hari. Metode yang digunakan dalam penelitian ini adalah kuantitatif yaitu melakukan penelitian dengan menyebarkan angket kepada remaja, kemudian dianalisis melalui deskripsi atau pemaparan hasil. Di samping itu penulis juga melakukan studi kepustakaan dan wawancara kepada gembala, pembina remaja. Berdasarkan penelitian dapat disimpulkan bahwa pengaruh pelayanan remaja terhadap pertumbuhan rohani remaja usia 12-15 tahun di Gereja Kemah Injil Indonesia Jemaat Antutan untuk membimbing remaja bertumbuh dalam kasih, cinta pelayanan, dan perubahan karakter.
\end{abstract}

Kata-kata Kunci: Pelayanan, Pertumbuhan Rohani Remaja, Remaja.

\section{Pendahuluan}

\section{Latar Belakang Masalah}

Anak adalah Anugrah Tuhan yang diberikan bagi orang tua. Anak tumbuh dan berkembang dalam keluarga. Orang tua merupakan perantara Allah sendiri untuk merawat dan mendidik anak yang dipercayakan dipangkuan ayah dan ibu. Dari masa bayi, kanakkanak sampai masa remaja orang tua mempunyai peran yang penting bagi perkembangan baik fisik secara khusus mental dan spiritual seorang anak. Hal yang paling utama bagi perkembangan anak adalah karakter atau sikap hidup yang akan menentukan kehidupan di masa yang akan datang.

Setiap orang tua pasti menginginkan anak mereka hidup lebih baik dari pada hidup orang tua sendiri. Oleh sebab itu banyak orang tua menggunakan berbagai macam cara 
pengajaran untuk menuntun anak mereka selalu berada di jalan yang benar. Karena pengajaran yang orang tua berikan kepada seorang anak terbatas dan harus dibantu oleh orang lain yang sesuai dengan profesi dan keahlian orang tersebut.

Menjelang usia 4 tahun dan seterusnya maka orang tua memberikan anak-anak untuk diajar oleh orang lain melalui lembaga pendidikan. Lembaga pendidikan formal atau non formal masing-masing tujuannya agar anak memiliki dan mengembangkan ilmu pengetahuan secara wawasan (kognitif). Bidang pendidikan di dunia sekuler sangat membantu anak mengalami suatu perkembangan dalam segi intelektual mereka. Namun selain di sekolah sekuler anak-anak juga dipercayakan oleh orang tua mereka untuk di didik melalui lembaga gereja yaitu melalui pembinaan atau bimbingan seorang pelayan dari masa kecil mereka (praindria) sampai usia remaja.

Untuk mendidik dan membimbing anak usia kecil yaitu 2 tahun sampai 11 tahun merupakan dasar yang paling penting ditanamkan pengetahuan tentang agama karena usia ini adalah usia yang mudah untuk membentuk pola pikir mereka karena pikiran mereka belum terkontaminasi dengan keadaan dan situasi lingkungan luar di mana mereka berada atau bergaul. Sedangkan usia 12 tahun sampai 17 tahun adalah usia di mana seorang anak sudah ada pada usia remaja. Usia remaja adalah usia yang rentan dengan kepribadian mereka sendiri dan pengaruh lingkungan yang ada di sekitar mereka. Masa remaja merupakan masa transisi atau peralihan dari masa anak menuju masa dewasa. ${ }^{1}$ Pada masa remaja individu mengalami berbagai perubahan baik fisik maupun psikis.

Perilaku menyimpang di kalangan remaja merupakan bagian dari kemerosotan kerohanian remaja itu sendiri dan kurangnya keberfungsian keluarga atau orang tua dalam mendidik hal spiritual kepada remajanya. Berdasarkan hasil penelitian penulis di Antutan rata-rata remaja yang memiliki kehidupan spiritual yang masih kurang disebabkan oleh beberapa faktor antara lain pelayanan yang kurang dilaksanakan dan orang tua yang sudah sibuk dengan urusan mereka masing-masing sehingga untuk meluangkan waktu dan memperhatikan anak-anaknya sudah sangat berkurang oleh sebab itu mereka mudah terpengaruh dengan lingkungan-lingkungan yang tidak baik yang ada di sekitar mereka.

Hal inilah yang membuat pembina remaja harus berusaha memberikan pelayanan yang bisa membantu remaja memiliki kehidupan rohani yang baik serta melakukan pembimbingan dengan menggunakan strategi yang tepat dan benar guna untuk membentuk mereka menjadi seperti karakter Kristus. Selain itu aktivitas remaja sehari-hari hampir lebih banyak di luar lingkungan rumah yaitu mereka lebih banyak berada dan bergaul dengan masyarakat luas. Dalam lingkungan masyarakat para remaja diperhadapkan dengan berbagai macam situasi karena lingkungan masyarakat merupakan lembaga pendidikan selain keluarga dan sekolah yang akan membentuk kebiasaan, pengetahuan, minat, dan sikap, kesusilaan, kemasyarakatan dan keagamaan seorang remaja. ${ }^{2}$ Sehingga setiap hal yang didapatkan oleh remaja ini terkadang dapat membawa pengaruh yang besar dalam kehidupan termasuk dalam hal spiritual mereka. Orang tua harus mengetahui kehidupan anak di luar rumah khususnya di lingkungan di mana kaum remaja ini bergaul. Aktivitas remaja seharihari hampir lebih banyak di sekolah dan di luar rumah yaitu mereka lebih banyak berada dan bergaul dalam masyarakat yang luas. Dalam masyarakat inilah remaja banyak diperhadapkan dengan berbagai macam situasi baik hal yang positif dan hal yang negatif. Sehingga apa yang didapatkan dalam pergaulan di masyarakat kadangkala menguasai diri seorang anak terutama remaja di manapun dia berada hal yang didapatkan dalam pergaulan tersebut akan diterapkan

\footnotetext{
${ }^{1}$ Dame Taruli Simamora, Pendidikan Agama Kristen kepada Remaja dan Pemuda (Medan: Rida Gultom, 2015), 13.

${ }^{2}$ Hasbullah, Dasar-Dasar Ilmu Pendidikan (Jakarta: Raja Grafindo Persada, 1999), 177.
} 
dalam kehidupannya baik itu yang positif ataupun yang negatif. ${ }^{3}$ Oleh karena itu penting bagi orang tua dan gereja memperhatikan anak -anak ini untuk membantu mereka mengambil keputusan yang ada sehingga mereka tidak salah dalam menjalani kehidupan kedepannya dalam hal ini kehidupan rohani. Usia remaja yang merupakan usia yang rentan bagi anakanak di mana mereka sedang mencari jati diri yang sebenarnya. Pada masa inilah kaum remaja mudah terpengaruh atau terbawa dengan arus pergaulan karena mereka belum bisa menentukan apa yang menjadi tujuan hidup mereka.

Pada umumnya tingkah laku seseorang akan berkaitan dengan gagasan-gagasan tentang diri atau konsep diri yang merupakan gambaran seseorang tentang dirinya dan dibentuk melalui pengalaman-pengalaman yang diperoleh melalui interaksi dengan lingkungan. Pengalaman-pengalaman hasil interaksi dengan lingkungan kemudian akan dicerna, dievaluasi yang kemudian menghasilkan proses pengenalan diri.

Proses pengenalan diri secara menyeluruh menghasilkan konsep diri pada diri seseorang. Konsep diri ada dalam bentuk konsep yang positif dan negatif. Individu yang memiliki konsep diri positif akan memiliki perasaan positif di dalam diri terkait identitas diri yang lebih baik serta mengevaluasi diri dengan lebih positif. Sebaliknya konsep diri yang rendah atau negatif pada seseorang akan memunculkan hal negatif tentunya akan menimbulkan perilaku negatif. ${ }^{4}$

Oleh sebab itu pembina atau pelayan remaja harus memiliki pelayanan yang lebih menarik perhatian remaja karena di zaman modern ini tidak dapat dipungkiri bahwa remaja lebih tertarik pada hal yang baru dan terlebih media sosial maka dari itu perlu menciptakan pelayanan yang kreatif bagi kaum remaja sehingga mereka tidak merasa jenuh dan bosan dalam ibadah remaja yang diadakan.

Pertumbuhan remaja merupakan proses perkembangan perilaku mereka bila seorang pelayan remaja ingin melayani remaja maka perlu banyak waktu agar dapat mengamati dan melihat proses tumbuh kembang remaja dan bagaimana perilaku mereka dalam kesehariannya supaya dapat menolong remaja pada pemahaman dan tindakan yang baik untuk melalui masa tersebut. ${ }^{5}$ Oleh karena itu seorang pembina atau pelayan remaja harus kreatif sehingga remaja yang dilayani dapat menerima dan tertarik apa yang disampaikan.

Karena melihat pada masa ini remaja diperhadapkan dengan zaman internet yang memudahkan remaja untuk mengakses berbagai macam informasi. Semua realita teknologi ini memampukan remaja berhubungan dengan dunia dan sebaliknya dunia berhubungan dengan remaja sehingga remaja lebih tertarik dengan media sosial yang mereka miliki. ${ }^{7} \mathrm{Hal}$

${ }^{3}$ Hana Duka, Peranan Guru Kristen Sebagai Pembimbing dalam Penangulangan Perkelahian Kelompok di Lingkungan SMP Kristen Makassar (Skripsi S. Pd.K, Sekolah Tinggi Theologia Jaffray Makassar, 2017), 3.

${ }^{4}$ Singgih D. Gunarsa \& Yulia Singgih D. Gunarsa, Psikologi Perkembangan Anak dan Remaja (Jakarta: BPK Gunung Mulia), 237.

${ }^{5}$ Jonathan Matheus, Elisabet Selfina, "Peran Pembina Remaja bagi Perkembangan Perilaku Remaja di Gereja Kemah Injil Indonesi Tanjung Selor Kalimantan Utara,” Jurnal Jaffray 13, no. 1 (April 2015): 6, diakses 3 September 2019. https://ojs.sttjaffray.ac.id.index.php/JJV71/article/view/3.

${ }^{6}$ Yuliana Banni and Elisabet Selfina, "Peran Orang Tua Tunggal Dalam Membimbing Anak Remaja Mencapai Kualitas Hidup Di Gereja Kibaid Klasis Makassar,” Jurnal Jaffray 9, no. 2 (October 2, 2011): 123-46, https://doi.org/10.25278/jj71.v9i2.98; Frans Geras and Elisabet Selfina, "Peranan Perempuan Dalam Mengembangkan Pelayanan Di Gereja Kemah Injil Indonesia Daerah III Nabire Papua,” Jurnal Jaffray 10 , no. 1 (April 1, 2012): 87-109, https://doi.org/10.25278/jj71.v10i1.64; Elsyana Nelce Wadi and Elisabet Selfina, "Peran Orang Tua Sebagai Keluarga Cyber Smart Dalam Mengajarkan Pendidikan Kristen Pada Remaja GKII Ebenhaezer Sentani Jayapura Papua,” Jurnal Jaffray 14, no. 1 (March 14, 2016): 77-92, https://doi.org/10.25278/jj71.v14i1.190.

${ }^{7}$ Gary Chapman, Membangun Masa Remaja Yang Sehat dan Penuh Makna dengan Lima Bahasa Cinta (Yogyakarta: ANDI, 2018), 18-19. 
inilah juga yang menjadi tantangan bagi pelayan untuk memberikan pelayanan kepada remaja masa kini baik yang di kota besar maupun di desa. Oleh karena itu setiap pelayanan yang ingin diberikan kepada remaja harus mengikuti perkembangan zaman atau lebih kreatif.

Dalam memberikan pelayanan kepada kaum remaja pembina perlu perlu mengikuti keteladanan Yesus dalam malakukan pelayanan dan pengajaran dengan tujuan akhir yaitu pertobatan dan pembaharuan hidup serta kekuatan akan firman Allah dan dapat mempraktekkannya dalam kehidupan sehari-hari. Selain mengajar Yesus sangat dekat dengan murid-murid-Nya sehingga terjadi keakraban diantara mereka. Tidak hanya memberikan pelayanan saja tetapi sebagai pelayan remaja perlu mendekatkan diri kepada mereka untuk mempermudah memberi pelayanan yang lebih maksimal.

Di dalam pengajaran-Nya, Tuhan Yesus mengajar dengan menjawab kebutuhankebutuhan murid-murid-Nya. Yesus konsisten dengan kebenaran dalam pengajaran-Nya, dan dinyatakan dengan penuh cinta kasih. Dengan segenap hati Yesus bergumul dan berjuang menyampaikan kebenaran kepada setiap orang. Hasilnya muridmuridnya dapat menularkan cara hidup yang benar. Selain itu Yesus sabar dalam menghadapi murid-murid-Nya, bahkan orang-orang yang mengikut Dia. ${ }^{8}$ Jadi jika seorang pembina atau pelayan remaja dalam melakukan pelayanan kepada remaja perlu mengikuti keteladanan Yesus yaitu dengan membangun hubungan yang intim (dekat) dengan remaja tidak hanya sekedar berteori tetapi perlu dipraktekan melalui kehidupan sehari-hari dengan remaja seperti Yesus dengan murid-murid-Nya sehingga remaja ini dapat menjadi dampak bagi orang yang disekitar mereka.

Tidak hanya itu seorang pembina remaja perlu mengetahui bahwa setiap remaja memiliki tempramen berbeda jadi perlu bagi seorang pembina melayani menyesuaikan diri dengan kaum remaja tersebut sebab setiap anak diwarisi tempramen dasar dari orangtua yang terdiri dari tempramen yang baik dan yang tidak baik. Tempramen ini di dalam Alkitab disebut dengan berbagai macam sebutan diantaranya manusia duniawi, daging, manusia lama dan benih yang fana itu adalah dorongan dasar tubuh seseorang yang selalu mencari kepuasan bagi keinginan-keinginan seseorang. ${ }^{9}$ Jadi dalam hal ini seorang pelayan remaja harus tahu latar belakang dari remajanya sehingga dapat diketahui bagaimana tempramen mereka.

Selain adanya perbedaan tempramen. Kelompok usia ini perlu mempertajam perasaan untuk membedakan yang benar dan yang salah karena mempunyai hasrat untuk diterima, mereka menjadi sensitif dengan suara hati. Problem moral utama mereka adalah perbuatan tidak terpuji. Mereka berhasrat untuk belajar termasuk belajar untuk bertanggung jawab. ${ }^{10}$ Tantangan bagi pelayan remaja masa kini sangat kompleks baik dari dalam diri remaja maupun dari luar diri remaja itu sendiri sehingga tidaklah mudah untuk melakukan pembimbingan terhadap remaja zaman ini. Pelayanan remaja dapat dilakukan dengan mengadakan perkunjungan kepada remaja untuk mengetahui kehidupan remaja dan keluarga. Perkunjungan menjadi bagian pelayanan terhadap remaja karena melalui perkunjungan dapat memperoleh informasi tentang latar belakang kaum remaja tersebut.

Sesuai dengan fakta yang terjadi di Antutan Kalimantan Utara ada fenomena yang terjadi mengenai remaja antara lain; terbentuknya kelompok remaja yang menyebabkan kerohanian mereka tidak terbentuk mereka memang dari keluarga keristen bahkan rajin mengikuti ibadah dan kegiatan rohani yang dilakukan dalam gereja serta mengambil bagian

\footnotetext{
${ }^{8}$ Chapman, 18-19.

${ }^{9}$ Tim Lahaye, Tempramen Anda Dapat Diubah (Bandung: Kalam Hidup, 2005), 7.

${ }^{10}$ Paulus Lilik Kristanto, Prinsip \& Praktik Pendidikan Agama Kristen (Yoyakarta: ANDI, 2006),
} 
dalam pelayanan namun masih banyak kerohanian mereka tidak terbentuk benar dan menyimpang dari norma-norma yang ada. Fenomena inilah yang harus diselesaikan oleh setiap gereja dan pelayan remaja dengan cara pembimbingan yang maksimal

Dari pengamatan yang dilakukan oleh penulis selama berada di Antutan setiap minggu pelayanan remaja rutin di laksanakan namun hanya ada beberapa remaja saja yang berubah dan memiliki kerohanian yang benar. Lebih banyak dari remaja ini yang kurang memiliki kerohanian yang tidak terbentuk dan sebagian besar tidak mengalami yang namanya perubahan dalam kehidupan mereka. Penjelasan yang diberikan salah satu pelayan remaja melalui wawancara bahwa ada banyak remaja yang menyimpang dari kebenaran firman Tuhan beberapa remaja dapat membuat rokok baik itu dari pipa ataupun dari bendabenda yang lain, minum-minuman keras, merokok sebelum ibadah remaja di laksanakan, selain itu dalam kelangsungan ibadah remaja sibuk dengan diri sendiri dan handphone masing-masing. Remaja yang hadir dalam ibadah hanya sebagai rutinitas seperti yang biasa dilakukan setiap minggu sehingga hal inilah yang membuat diri mereka tidak fokus dengan ibadah dan setiap materi Firman Tuhan yang disampaikan tidak diterima dengan baik. Meskipun setiap minggu ibadah remaja di laksanakan namun yang memiliki kerohanian terbentuk hanya sebagian kecil saja dan kenakalan remaja masih tetap terjadi pada remaja jadi sebagai seorang pelayan remaja perlu mencari solusi dan mempunyai strategi yang dapat membangun pertumbuhan rohani anak remaja

Di sisi lain orang tua remaja ini sebagian berprofesi sebagai petani atau berkebun sesuai dengan pengamatan penulis secara langsung di lapangan bahwa yang menjadi sebagian penghambat pertumbuhan rohani remaja di Antutan Kalimantan Utara ialah orang tua yang sibuk dengan pekerjaannya sehingga orang tua kurang memiliki waktu untuk berkomunikasi (Sharing firman Tuhan) serta kurangnya pengawasan kepada kaum remaja mengakibatkan remaja di Antutan akhirnya terjerumus dengan masalah-masalah kenakalan remaja. Oleh karena kesibukan itulah orang tua tidak dapat membimbing remaja khususnya dalam hal pertumbuhan kerohanian mereka.

Selain itu ada sebagian remaja yang memiliki latar belakang masalah keluarga dan lingkungan di mana mereka tinggal sehingga inilah yang menyebabkan tidak ada pengaruh pelayanan remaja terhadap pertumbuhan rohani mereka disebabkan tidak adanya yang membimbing mereka dalam hal rohani. Tentunya banyak pembina remaja yang mempunyai kemampuan untuk melakukan pembimbingan bagi remaja ini. Tetapi tanpa bantuan dari orang tua, gereja dan sekolah hal ini sulit untuk diselesaikan. Pengarahan melalui bimbingan dan daya control harus dilakukan sehingga remaja ini dapat memiliki karakter yang baik dan pertumbuhan rohani yang sehat serta iman yang bertumbuh.

\section{Pokok Masalah}

Berdasarkan latar belakang masalah di atas maka yang menjadi pokok masalah yang diajukan pada penelitian ini adalah sejauh mana pengaruh pelayanan remaja terhadap pertumbuhan rohani remaja usia 12-15 tahun di Gereja Kemah Injil Indonsia Jemaat Antutan Kalimantan Utara?

\section{Tujuan Penelitian}

Merujuk pada pokok masalah di atas, maka tujuan penelitian yang hendak di pakai adalah untuk mengetahui sejauh mana pengaruh pelayanan remaja terhadap pertumbuhan rohani remaja usia 12-15 tahun di Gereja Kemah Injil Indonesia Jemaat Antutan Kalimantan Utara. 


\section{Manfaat Penelitian}

Pertama, dengan penulisan skripsi ini kiranya dapat menjadi pedoman bagi penulis sebagai pengajar di lingkungan di mana penulis itu berada. Penelitian ini diharapkan dapat menjadi kontribusi pemikiran bagi semua Civitas Akademika Sekolah Tinggi Filsafat Jaffray Makassar khususnya dalam pengembangan tentang pentingnya pelayanan remaja untuk kerohanian remaja.

Kedua, penelitian ini diharapkan dapat menjadi masukan bagi gereja dan pelayan remaja untuk menyadari dan melaksanakan peranannya dalam pertumbuhan kerohanian remaja.

Ketiga, penelitian ini diharapkan dapat menjadi kontribusi pemikiran bagi semua Civitas Academica Sekolah Tinggi Filsafat Jaffray Makassar khususnya dalam pengembangan tentang pentingnya pelayanan remaja.

Keempat, sebagai persyaratan untuk menyelesaikan pendidikan stratum satu (S1) pada Sekolah Tinggi Filsafat Jaffray Makassar.

\section{Batasan Penelitian}

Ruang lingkup pembahasan skripsi ini penulis hanya membatasi sejauh mana pengaruh pelayanan remaja terhadap pertumbuhan kerohanian remaja usia 12-15 tahun di Gereja Kemah Injil Indonesia Jemaat Antutan Kalimantan Utara.

\section{Metode Penelitian}

Adapun metode penelitian yang digunakan dalam penyusunan skripsi ini yaitu kuantitatif $^{11}$ dengan teknik pengumpulan data: ${ }^{12}$

Pertama, penulis menggunakan kajian pustaka, yaitu dengan mengumpulkan data melalui buku-buku dan internet yaitu jurnal yang berhubungan dengan pengaruh pelayanan remaja terhadap pertumbuhan kerohanian remaja usia 12-15 tahun di Gereja Kemah Injil Indonesia Jemaat Antutan Kalimantan Utara. Penelitian yang relevan dengan topik ini adalah tema remaja dan kompetensi yang dibutuhkan dalam pelayanan. ${ }^{1314}$

\footnotetext{
${ }^{11}$ Hengki Wijaya, Metodologi Penelitian Pendidikan Teologi (Makassar: Sekolah Tinggi Theologia Jaffray Makassar, 2016).

${ }^{12}$ Helaluddin Helaluddin and Hengki Wijaya, Analisis Data Kualitatif: Sebuah Tinjauan Teori \& Praktik (Makassar: Sekolah Tinggi Theologia Jaffray Makassar, 2019); Hengki Wijaya, Analisis Data Kualitatif Ilmu Pendidikan Teologi (Makassar: Sekolah Tinggi Theologia Jaffray Makassar, 2018).

${ }^{13}$ Banni and Selfina, "Peran Orang Tua Tunggal Dalam Membimbing Anak Remaja Mencapai Kualitas Hidup Di Gereja Kibaid Klasis Makassar."

${ }^{14}$ Mika Mika and Petronella Tuhumury, "Implementasi Strategi Pembinaan Menuju Pertumbuhan Rohani Pemuda Gkii Jemaat Sidu'ung Muara Berau," Jurnal Jaffray 11, no. 2 (October 2, 2013): 191-208, https://doi.org/10.25278/jj71.v11i2.84; Elisabet Selfina, "Strategi Pertumbuhan Gereja Melalui Pendidikan Anak Usia Dini," Jurnal Jaffray 11, no. 1 (April 2, 2013): 87-108, https://doi.org/10.25278/jj71.v11i1.65; Harmelia Tulak et al., "The Intercultural Competence in Education Era 4.0: A Learning Strategy for Students of Elementary School in Indonesia," in Proceedings of the Proceedings of the 1st International Conference of Science and Technology in Elementary Education, ICSTEE 2019, 14 September, Makassar, South Sulawesi, Indonesia (Proceedings of the 1st International Conference of Science and Technology in Elementary Education, ICSTEE 2019, 14 September, Makassar, South Sulawesi, Indonesia, Makassar, Indonesia: EAI, 2019), https://doi.org/10.4108/eai.14-92019.2289961; Helaluddin Helaluddin and Hengki Wijaya, "Pengembangan Kompetensi Pendidik Di Perguruan Tinggi Dalam Menyonsong Era Revolusi Industri 4.0” (Makassar: Universitas Fajar Makassar, 2019), https://repository.sttjaffray.ac.id/id/publications/273069/pengembangan-kompetensi-pendidik-di-perguruan-tinggidalam-menyonsong-era-revolu.
} 
Kedua, penulis akan menggunakan observasi lapangan, yaitu dengan menggunakan angket dan pertanyaan. Angket ini disebarkan kepada remaja untuk mendapatkan data yang lebih mendalam tentang pelayanan remaja terhadap petumbuhan rohani remaja usia 12-15 tahun di Gereja Kemah Injil Indonesia Jemaat Antutan Kalimantan Utara.

\section{Sistematika Penulisan}

Bab pertama, merupakan pendahuluan yang menguraikan tentang latar belakang masalah, pokok masalah, tujuan penelitian, manfaat penelitian, metode penelitian, batasan penelitian, dan sistematika penulisan.

Bab kedua, merupakan tinjauan pustaka yang membahas mengenai pengertian remaja, ciri-ciri remaja, pengertian pengaruh pelayanan remaja, dasar Alkitab pelayanan remaja, pelayanan remaja alam perjanjian lama, pelayanan remaja dalam perjanjian baru, bentuk-bentuk pelayanan remaja, pertumbuhan rohani, definisi pertumbuhan rohani, pentingnya pertumbuhan rohani, tujuan pertumbuhan rohani, manfaat pertumbuhan rohani, unsur-unsur pertumbuhan rohani, pengaruh pelayanan terhadap pertumbuhan rohani remaja.

Bab ketiga, merupakan metodologi penelitian yang membahas mengenai gambaran umum lokasi penelitian, jenis penelitian, teknik pengumpulan data, dan teknik analisa data.

Bab keempat, merupakan analisis hasil penelitian serta kesimpulan analisis hasil penelitian yang dilakukan di lapangan.

Bab kelima, merupakan kesimpulan dan saran

\section{Kesimpulan}

Dari hasil penelitian dan pembahasan mengenai Pengaruh Pelayanan Remaja Terhadap Pertumbuhan Rohani Remaja Usia 12-15 Tahun Di Gereja Kemah Injil Indonesia Jemaat Antutan.di simpulkan bahwa

Pertama, pelayanan yang diberikan kepada remaja di Gereja Kemah Injil Indonesia Jemaat Antutan Kalimantan Utara antara lain, ibadah kreatif yang didalamnya nonton bersama diperoleh rata-rata $32 \%$ remaja tertarik dan terberkati sedangkan games (permaianan) diperoleh rata-rata $80 \%$ remaja tertarik dan terlibat. Selain itu kuis Alkitab diperoleh rata-rata $56 \%$ remaja tertarik, terlibat dan terberkati. 42,66\% remaja senang, terberkati serta terlibat dalam pelayanan perkunjungan.

Jadi pelayanan yang dilakukan kepada remaja dalam bentuk nonton bersama masih kurang diminati oleh remaja sedangkan games dan kuis Alkitab remaja sangat tertarik dan mau ikut terlibat.

Kedua, pertumbuhan rohani remaja diperoleh rata-rata $60 \%$ remaja memiliki perubahan karakter dan $46 \%$ remaja terlibat pelayanan yang dilakukan. Oleh karena itu dapat disimpulkan bahwa remaja memiliki pertumbuhan rohani seperti remaja memiliki perubahan karakter sedangkan keterlibatan remaja dalam pelayanan masih kurang. Dan hasil wawancara yang dilakukan oleh penulis kepada remaja menyatakan bahwa remaja kurang dilibatkan dalam pelayanan remaja yang dilakukan.

Ketiga, pengaruh pelayanan remaja terhadap pertumbuhan rohani remaja diperoleh adalah 99,96\%. Jadi dari interval koefisien korelasi memiliki tingkat hubungan yang sangat kuat, dengan nilai 0,999. Maksudnya adalah pengaruh pelayanan remaja terhadap pertumbuhan rohani remaja memiliki hubungan yang sangat kuat karena pelayanan yang 
diberikan kepada remaja diterima dengan baik oleh remaja sehingga remaja dapat mencapai pertumbuhan rohani baik itu dari perubahan karakter dan terlibat pelayanan yang dilakukan.

\section{Saran-saran}

Melihat keadaan pada remaja di Gereja Kemah Injil Indonesia di Jemaat Antutan Kalimantan Utara, maka melalui karya ilmiah ini penulis ingin memberikan beberapa saran yang berkaitan dengan pengaruh pelayanan remaja terhadap pertumbuhan rohani remaja yaitu sebagai berikut:

Pertama, dalam melakukan pelayanan kepada kaum remaja perlu bagi pembina mempunyai program untuk membuat remaja selalu tertarik dan terlibat dalam ibadah remaja seperti mempersiapkan ibadah-ibadah kreatif seperti nonton bersama, kuis Alkitab.

Kedua, perlunya diadakan pendekatan melalui perkunjungan secara pribadi oleh pengurus atau pembina remaja untuk memberikan bimbingan dan motivasi, mengingkatkan minat serta kehadiran remaja dalam setiap kegiatan ibadah remaja.

Ketiga, pembina remaja dalam melakukan pelayanan dapat melibatkan gembala, dan orang tua sehingga pembina remaja dapat saling membagi informasi mengenai perkembangan perilaku anak-anak baik dirumah maupun di luar rumah.

\section{Kepustakaan}

Alkitab. Jakarta: Lembaga Alkitab Indonesia, 2001.

Ali, Mohammad. Penelitian Kependidikan Prosedur dan Strategi. Bandung: Angkasa, 2013. Allen, Shelly, Judith. Kebutuhan Rohani Anak. Bandung: Kalam Hidup, 2003.

Artherburn, Stephen \& Jim Burns. Arahkan Dengan Jitu. Yogyakarta: ANDI, 2006.

Bambarehi, Rosyanthi, Ferayanthi, dan Ivone Bonyadone Palar. "Formasi Rohani

Seorang Pelayanan Anak Dalam Menunjang Efektivitas Pelayanan.” Jurnal Jaffray 9, no. 1 (2011): 1-30. Diakses 4 September 2019.

https://ojs.sttjaffray.ac.id/index.php/JJV71/article/view/94.

Banni, Yuliana, and Elisabet Selfina. "Peran Orang Tua Tunggal Dalam Membimbing Anak Remaja Mencapai Kualitas Hidup Di Gereja Kibaid Klasis Makassar.” Jurnal Jaffray 9, no. 2 (October 2, 2011): 123-46. https://doi.org/10.25278/jj71.v9i2.98.

Bons-Storm, M. Apakah Pengembalaan itu? Jakarta: BPK Gunung Mulia, 2008.

Brill, J. Wesley. Dasar Yang Teguh. Bandung: Kalam Hidup, 2003.

Chapman, Gery. Membangun Masa Remaja Yang Sehat dan Penuh Makna Dengan Lima

Bahasa Cinta. Yoyakarta: ANDI, 2018.

Charles, Shelton. Moralitas Kaum Muda. Yogyakarta: Kanisius: 2003.

David, Tripp, Paul. Masa Penuh Kesempatan. Surabaya: Momentum, 2007

Duka, Hana. "Peranan Guru Kristen Debagai Pembimbing Dalam Penangulangan Perkelahian Kelompok Di Lingkungan SMP Kristen Makassar.” Skripsi, S.Pd.K, Sekolah Tinggi Theologia Jaffray, 2017.

Elis, D. W. Metode Penginjilan. Jakarta: Yayasan Komunikasi Bina Kasih/OMF, 1999. 
Edowai, Dolince. "Pengaruh Ibadah Persekutuan Mahasiswa Papua (IPMP) Terhadap Pertumbuhan Rohani Mahasiswa Papua Di Kota Makassar." Skripsi S. Pd.K, Sekolah Tinggi Theologia Jaffray, 2017.

Geras, Frans, and Elisabet Selfina. "Peranan Perempuan Dalam Mengembangkan Pelayanan Di Gereja Kemah Injil Indonesia Daerah III Nabire Papua.” Jurnal Jaffray 10, no. 1 (April 1, 2012): 87-109. https://doi.org/10.25278/jj71.v10i1.64.

Gunarsa, Singgih, D. \& Yulia Singgih D. Psikologi Perkembangan Anak dan Remaja. Jakarta: BPK Gunung Mulia, 2011.

Guthrie, Donald. Teologi Perjanjian Baru 3. Jakarta: BPK Gunung Mulia, 1993.

Hadfeld, Robin \& Maricia. Pedoman Pelayanan Remaja Dan Pemuda. Batu Malang: YPPII, 1979.

Hasbullah. Dasar-dasar Ilmu Pendidikan. Jakarta: Raja Grafindo Persada, 1999.

Helaluddin, Helaluddin, and Hengki Wijaya. Analisis Data Kualitatif: Sebuah Tinjauan Teori \& Praktik. Makassar: Sekolah Tinggi Theologia Jaffray Makassar, 2019. - "Pengembangan Kompetensi Pendidik Di Perguruan Tinggi Dalam Menyonsong Era Revolusi Industri 4.0.” Makassar: Universitas Fajar Makassar, 2019. https://repository.sttjaffray.ac.id/id/publications/273069/pengembangan-kompetensipendidik-di-perguruan-tinggi-dalam-menyonsong-era-revolu.

Hutchcraft, Ron \& Lisa Hutchcraft Whitmer. Perjuangan untuk Sebuah Generasi. Jakarta: Metanoia Publishing, 2004.

Ismal, Andar. Ajarlah Mereka Melakukan. Jakarta: BPK Gunung Mulia, 2010.

Ipui, Philip. "Analisis Pola Pelayanan Remaja Terhadap Perkembangan Kerohanian Remaja Usia 12-15 Di Gereja Kemah Injil Indonesia Jemaat Antutan Kalimantan Utara." Skripsi, S.Pd.K, Sekolah Tinggi Theologia Jaffray, 2015.

Jonathan, Matheus \& Elisabet Selfina. "Peran Pembina Remaja bagi Perkembangan Perilaku Remaja di Gereja Kemah Injil Indonesia Tanjung Selor Kalimantan Utara.” Jurnal Jaffray. 13, no. 1 (2015): 1-22. Diakses 5 September 2019. https://ojs.sttjaffray.ac.id/index.php/JJV71/article/view/3.

Juliana, Ester. "Pengaruh Pola Pembinaan Orang Tua Terhadap Kualitas Kerohanian Remaja di Gereja Kemah Injil Indonesia Jemaat Kelubir Kalimantan Utara.” Skripsi S.Pd.K, Sekolah Tinggi Theologia Jaffray, 2015.

Kenny, James \& Mary Kenny. Dari Bayi Sampai Dewasa. Jakarta: BPK Gunung Mulia. 1991.

Lahaye, Tim. Tempramen Anda Dapat Diubah. Bandung: Kalam Hidup, 2005.

Paulus, Lilik, Kristanto. Prinsip \& Praktik pendidikan Agama Kristen. Yokyakarta: ANDI, 2006.

Linda dan Ricard Eyre. Mengajar Nilai-nilai pada Anak. Jakarta: Gramedia Pustaka Utama, 1999.

John, M, Nainggolan. Menjadi Guru Agama Kristen. Bandung: Generasi Info Media, 2007.

Maiaweng, Peniel C. D. Kelompok Penelaahan Alkitab. Makassar: Sekolah Tinggi Theologia Jaffray Makassar, 2013.

Mika, Mika, and Petronella Tuhumury. "Implementasi Strategi Pembinaan Menuju Pertumbuhan Rohani Pemuda Gkii Jemaat Sidu'ung Muara Berau." Jurnal Jaffray 11, no. 2 (October 2, 2013): 191-208. https://doi.org/10.25278/jj71.v11i2.84.

Mulyono, Y Bambang. Kenakalan Remaja. Yogyakarta: ANDI, 1986.

Natsir, Moh. Metode Penelitian. Jakarta: Ghalia Indonesia, 1988. 
Nofandi. "Peran Badan Pengurus Jemaat dalam Meningkatkan Pertumbuhan Kerohanian Pemuda Gereja Kristen Sulawesi Barat Efata di Desa Salutiwo Mamuju." Skripsi S.Pd.K, Sekolah Tinggi Theologia Jaffray Makassar, 2016.

Nurliati. "Tinjau Terhadap Strategi pelayanan Di Gereja Kemah Injil Indonesia Harapan Baru Kecamatan Mentarang Malinau Kalimantan Utara." Skripsi S.Pd.K, Sekolah Tinggi Theologia Jaffray Makassar, 2015.

Paul, D Meyer. Pengantar Psikologi dan Konseling. Yogyakarta: ANDI, 2004.

F Mardi, Prasetya. Psikologi Hidup Rohani. Yogyakarta: Kanisius,1993.

R. Yahya. Memulai Hidup Baru. Jakarta: 1985.

Richards, Lawrence O. Mengajarkan Alkitab Secara Kreatif. Bandung: Kalam Hidup, 2000. Pelayanan Kepada Anak-anak. Bandung: Kalam Hidup, 2007.

Sanders, Bill. Dari Remaja Untuk Orang tua. Bandung: Kalam Hidup, 1995.

Selfina, Elisabet. "Strategi Pertumbuhan Gereja Melalui Pendidikan Anak Usia Dini." Jurnal Jaffray 11, no. 1 (April 2, 2013): 87-108. https://doi.org/10.25278/jj71.v11i1.65.

Setiawani, Mary Go. Pembaharuan Mengajar. Bandung: Kalam Hidup, 1993.

Sidjabat, B. S. Mengajar Secara Profesional. Bandung: Kalam Hidup 2009.

Silalahi, Maurits. Kuasa Yang Membawa Kemenangan. Kalam Hidup: 2015.

Simamora, Dame Taruli. Pendidikan Agama Kristen Kepada Remaja Dan Pemuda. Medan: Edisi 2.

Simanjuntak, Julianto \& Roswitha Ndraha. Bersahabat Dengan Remaja. Tangerang: Yayasan Pelikan Indonesia, 2014.

Slater, Tom. Melayani Melalui Kemp. Jakarta: Persekutuan Pembaca Alkitab, 2005.

Subagoyo, Andreas B. Pengantar Riset Kuantitatif Dan Kualitatif. Bandung: Yayasan Kalam Hidup, 2004.

Thompson, Marjorie L. Keluarga Sebagai Pusat Pembentukan. Jakarta: BPK Gunung Mulia, 2011.

Tulak, Harmelia, Hengki Wijaya, Susanna N. Rante, Nurmadiah Nurmadiah, and Helaluddin Helaluddin. "The Intercultural Competence in Education Era 4.0: A Learning Strategy for Students of Elementary School in Indonesia." In Proceedings of the Proceedings of the 1st International Conference of Science and Technology in Elementary Education, ICSTEE 2019, 14 September, Makassar, South Sulawesi, Indonesia. Makassar, Indonesia: EAI, 2019. https://doi.org/10.4108/eai.14-9-2019.2289961.

Tu'u, Tulus. Pemimpin Kristiani Yang Berhasil. Bandung: Bina Media Informasi, 2010.

Whitney, Donald S. Displin Rohani; 10 Pilar Penopang Kehidupan Kristen. Bandung:

Lembaga Literatur Babtis, 1994.

Wadi, Elsyana Nelce, and Elisabet Selfina. "Peran Orang Tua Sebagai Keluarga Cyber Smart Dalam Mengajarkan Pendidikan Kristen Pada Remaja GKII Ebenhaezer Sentani Jayapura Papua." Jurnal Jaffray 14, no. 1 (March 14, 2016): 77-92. https://doi.org/10.25278/jj71.v14i1.190.

Wijaya, Hengki. Analisis Data Kualitatif Ilmu Pendidikan Teologi. Makassar: Sekolah Tinggi Theologia Jaffray Makassar, 2018.

Wijaya, Hengki (ed.). Metodologi Penelitian Pendidikan Teologi. Makassar: Sekolah Tinggi Theologia Jaffray Makassar, 2016.

Yasperin. Rahasia Hidup Manusia. Jakarta: Yayasan Perpustakaan Injili, 1996.

Zarkasih, Khamim Putro."Memahami Ciri dan Tugas Perkembangan Masa Remaja.” Jurnal Aplikasi Ilmu-ilmu Agama. 17, no. 1 (2017): 25-35.

http://ejournal.uinsuka.ac.id/pusat/aplikasia/article/view/1362. 